\title{
Non-Formal Education in International Comparison: Patterns of Participation and Investment in Selected European Countries
}

\author{
Katrin Kaufmann \\ Freie Universität Berlin \\ Department of Education and Psychology \\ Empirical Research on Further Education \\ Arnimallee 12, 14195, Berlin, Germany \\ E-mail: katrin.kaufmann@fu-berlin.de
}

\begin{abstract}
This investigation focuses on participation and related investment patterns in job related non-formal education (NFE) in selected European countries. Broadening previous research formats of NFE are distinguished by investment including financial and time investments by employers, employees and public authorities. By this, company-sponsored and individual-financed NFE are distinguished sharply and cases with shared investment between employers and employees (co-financed NFE) and between employers, employees and public funding (co-financed pooled NFE) are accounted for, additionally. For explaining participation in NFE supply and demand models are referred to. Hypotheses on cross-country differences for investment in NFE refer to the Varieties-ofCapitalism approach and countries are selected representing different varieties of capitalism (Norway, Sweden, Germany, Lithuania, Latvia, Spain, France, UK). Analyses are based on data of the Adult Education Survey (AES) 2011/12.
\end{abstract}

Keywords: NFE, Participation, Investment Patterns, International Comparison, AES 2011, Vocational Education and Training

\section{Bibliographical notes:}

Katrin Kaufmann is Junior Professor of Empirical Research on Further Education at Freie Universität Berlin, Department of Education and Psychology. Her research interests focus on investment and participation patterns of non-formal education, informal learning and workplace learning and its interrelations. 


\section{Introduction and Overview}

International comparisons on adult education and training (AET) ${ }^{1}$ participation reveal substantial differences between countries. Countries with similar rates are often grouped, usually showing high participation rates in the Nordic Countries, low rates in the Southern European Countries, medium rates in the Anglo-saxon countries, and medium to low rates in the Post-socialists Central and Eastern European (CEE) countries (e.g. Bassanini et al. 2005; Desjardins et al. 2006; Boateng 2009; Green 2006; Roosmaa and Saar 2010, 2012; Rubenson 2006; Rubenson and Desjardins 2009). Even though the familiar pattern of advantaged groups participating in AET (employed, high-skilled, young age groups) is evident in all European member states, the extent of inequality in access differs substantially between countries. In general, research on hindering and promoting conditions for AET participation suggest a complex interplay of structurally determined conditions and individual characteristics (e.g. Desjardins et al. 2006; Rubenson 2006; Rubenson and Desjardins 2009; Roosmaa and Saar 2010, 2012). Thereby, recently developed models for explaining AET participation focus on the match of demand and supply aspects and more or less explicitly include macro level indicators as relevant framing conditions (e.g. Green 2006; Rubenson and Desjardins 2009; Boeren et al. 2010). International comparative analyses show that countries with a similar extent of inequality in access to AET also show considerable similarities in terms of economic systems, labour market policies and education and training systems (e.g. Roosmaa and Saar 2010, 2012).

Whereas international comparative research on the amount of (in)equality in access to AET has led to interesting insights regarding country differences (e.g. Desjardins et al. 2006; Rubenson und Desjardins 2009; Roosmaa und Saar 2010, 2012), international comparative investigations on investment patterns of AET have been done to limited extend (e.g. Brunello et al. 2007; Desjardins and Rubenson 2011). European data suggest that about 40 \% (Schönfeld and Behringer 2015, 307f. ff.) to $60 \%$ (Boateng 2009, 1) of employed participants in job related non-formal education (NFE) are sponsored fully or partly by employers and employers are the primary source supporting AET (Brunello et al. 2007, 197; Desjardins and Rubenson 2011, 56, FIBS und DIE 2013; Rubenson 2006, 228ff. ff.). ${ }^{2}$ If sources of investment are considered, determinants of AET participation differ substantially (e.g. Brunello et al. 2007; Desjardins and Rubenson 2011). An analysis for Germany suggests to distinguish strictly between company-sponsored and individual-financed AET and additionally to differentiate a co-financed format, where employers and employees share the investment, including time investment (Kaufmann and Widany 2013). Results show that co-investment in AET is of quantitative relevance and participation patterns differ from company-sponsored AET.

Referring to these findings this paper focuses on participation patterns in an international comparative perspective by distinguishing company-sponsored and individual-financed AET distinctively and additionally accounting for co-financed

\footnotetext{
${ }^{1}$ As definitions and concepts of adult education differ between surveys, Adult Education and Training (AET) is referred to as an overall term, including any organized format of education and training of adults.

${ }^{2}$ The share of employers financing adult education differs considerably depending on questionnaires and operationalization in the different survey concepts (e.g. Bassanini et al. 2005; Kaufmann and Widany 2013).
} 
formats where employers and employees and employers, employees and the state share the investment for job related AET. Thereby, monetary and time investments are considered. The first question is, whether co-financing AET is of relevance in other European countries, too, and whether participation rates differ between countries. The second question refers to country-specific participation patterns if these formats of AET are distinguished.

The paper is structured as follows: First, the state of research on cross-country differences of AET-participation is outlined and framed by theoretical approaches. Following, research results on hindering and promoting conditions for participation are presented if investment in AET is considered. The Varieties-of-Capitalism approach (VoC) allows to distinguish countries according to characteristics of labour markets and skill formation systems and thereby enables to derive assumptions regarding investment patterns in adult education and training (e.g. Dieckhoff et al. 2007, 84; Roosmaa and Saar 2010, 2012; Saar et al. 2013; Saar and Ure 2013, section 2). Section 3 defines the research question and countries selected for the analyses. Information on the data base (Adult Education Survey AES 2011), sample restrictions and descriptions are provided in section 4 and analytical results in section 5 . The paper closes with implications for further investigations.

\section{Theoretical framings and state of research}

\subsection{Cross-country differences of AET-participation}

Overall, participation in AET is regarded as the result of a complex interplay of structurally determined conditions and individual characteristics including situational, dispositional and institutional barriers (e.g. Desjardins et al. 2006; Roosmaa and Saar 2010; 2012; Rubenson 2006; Rubenson and Desjardins 2009). Recently developed models for explaining AET participation consider this reciprocal relation of individual and structural aspects and focus on the match of demand and supply patterns which are expected to mutually influence each other (e.g. Boeren et al. 2010; Green 2006; Rubenson and Desjardins 2009). Demand for AET can be pursued by individuals or firms; supply of AET can be arranged by adult education institutions but also by employers resp. firms.

The state of research on determinants of AET participation reflects these relations and some results are quite stable across countries. Generally, sociodemographic characteristics like high formal qualification grades and high literacy skills positively influence access to AET (e.g. Desjardins et al. 2006, 59ff.; Bassanini et al. 2005, 207ff.; Boateng 2009, 1ff.). The influence of age is not consistent. Brunello et al. (2007, 208f.) find that increasing age is negatively associated with participation in AET whereas Dieckhoff et al. (2007) do not find this pattern for Denmark, Finland and Ireland. Apart from individual related attributes, job related characteristics influence AET participation. This is presumably associated with the overall result of a large share of AET being jobrelated and supported by employers (Boateng 2009; Brunello et al. 2007; Desjardins and Rubenson 2011; FIBS and DIE 2013; Schönfeld and Behringer 2015). Being gainfully employed and in high resp. skill intense job positions, in large enterprises or the public sector, working full-time and on a permanent contract influence AET-participation positively (e.g. Desjardins et al. 2006, 59ff., 65; Brunello et al. 2007, 207ff.). Even though, these patterns are quite similar across countries, the extent of inequality in access to AET differs considerably 
between countries (e.g. Roosmaa and Saar 2012; Boateng 2009, 3f.). For explaining these cross-country differences, theoretical approaches address macrolevel indicators, which are assumed to shape specific conditions which in turn affect individual behaviour and also the supply for adult education. Whereas educational and sociological approaches focus primarily on education, training and skill formation systems for the explanation of differences in school-to-worktransitions (e.g. Allmendinger 1989; Brzinsky-Fay 2007; Gangl 2003), economic and political approaches address the relationship between state regulation and labour market systems for explaining international disparities in terms of economic and political structures (e.g. Esping-Andersen 1990; Estevez-Abé et al. 2001; Shavit et al. 1998). Hence, theoretical approaches originating from political, economic and sociological disciplines are getting into focus for explaining crosscountry differences in AET participation (e.g. Saar and Ure 2013). By this, macro level indicators like skill formation systems, education policies, labour market contexts and welfare state models are referred to, expecting to influence supply and demand for AET on the micro (individual) and meso (e.g. educational institutions/ firms as providers or suppliers) level.

Esping-Andersen (1990) distinguishes 'welfare state regimes' according to socio-political arrangements between state, market, and family. Central criterion for the distinction is the amount of decommodification resulting in three distinct welfare state regimes: Liberal welfare state regimes are characterized by meanstested assistance, modest universal transfers and social insurance plans (e.g. UK, Canada, Australia); conservative or corporatistic welfare state regimes are marked by state subsidiary responsibility following e.g. family support and status consistent rights of state assistance (e.g. Austria, Germany, France, Italy) and sociodemocratic welfare state regimes are described by equal citizen's right to services and benefits and integration of welfare and work (e.g. Nordic Countries) (ibid., 26ff.). Focusing on welfare states influencing individual perceptions, Rubenson and Desjardins (2009, 194ff.) propose a model of 'bounded agency'. Their descriptive results do not support the assumptions of diverse individual perceptions of barriers to participate in AET in different welfare state regimes. However, in the Nordic countries (sociodemocratic welfare state regimes) more individuals participate in AET despite perceived barriers. Further, results indicate less inequality in access to AET (ibid.) and a longer time spent in AET in these countries (Desjardins and Rubenson 2013). Analyses on firms providing training in different welfare state regimes also reveal mixed results. Positive correlations are detected between countries GDP/capita and the amount of firms providing training, yet, countries with a similar GDP/capita show considerable differences in the provision of firm-provided training (Markowitsch et al. 2013).

Another approach recently referred to for explaining cross-country differences in AET participation is the Varieties of Capitalism (VoC) approach, originally aiming on explaining country specific constitutions of political economies (Estevez-Abé et al. 2001; Hall and Soskice 2001). Thereby, interactions of specific actors, regulations and institutions are focused on and characteristics of the labour market and the skill formation system are explicitly included. One of the main arguments is the mutual influence resp. dependency of diverse actors, institutions and regulations conditionally shaping specific configurations of political economies (Hall and Soskice 2001, 5-7ff.; 15ff.). Emphasizing the role of economic enterprises, it is assumed that the nature of the established relationships influences companies' main coordination forms which in turn affect companies' 
product market strategies. This strategy is assumed to be influenced by rules and regulations set by the state, so welfare state regimes are relevant framing conditions. According to the assumption of mutual dependencies the established relationships and coordination forms in turn influence actions and behaviour of other actors. This is summarized by the term 'institutional complementarities' (ibid., 17), resembling what is meant by the term 'institutional packages' (Blossfeld 2003; Saar et al. 2013). Roughly speaking, labour market and skill formation system characteristics are assumed to interact as institutional complementarities and by this, conditionally shape specific configurations of political economies, which are termed 'welfare production regimes' (Hall and Soskice 2001, 5-7ff.;15ff.). Originally, two ideal types of political economy are distinguished: 'liberal market economies' (LME, e.g. USA) and 'coordinated market economies' (CME; e.g. Germany) (ibid., 8;19). The so called 'Mediterranean countries' constitute another variety of capitalism, including characteristics of both, liberal and coordinated market economies (ibid., 17ff.). Finally, the new EU member states of post-socialists Central and Eastern European (CEE) countries are characterized as 'dependent market economies' (DME), usually being dependent on international companies. Regarding labour markets and skill formation systems, welfare production regimes are characterized as follows (ibid. 10ff.; Estevez-Abé et al. 2001, 147ff.; Nölke and Vliegenthart 2009, 678ff.):

- LMEs and DMEs show a combination of weak employment and unemployment protection legislations and a general skill profile (e.g. USA, UK, Australia, Canada, New Zealand, Ireland as LME) resp. a medium general/industry-specific skill profile; Baltic States as DMEs).

- Contrarily CMEs are characterized by a combination of high protection of either employment or unemployment legislations and industry-specific or firm-specific skills (e.g. Austria, Germany, Switzerland, The Netherlands, Belgium, Sweden, Norway, Denmark, Finland, Japan).

- Mediterranean countries are somewhat in between: often characterized by medium social protection legislations and a general skill formation system and pronounced segmented labour markets (e.g. France, Italy, Spain, Portugal, Greece, Turkey).

Even though the VoC-approach refers primarily to initial education and training systems, assumptions for investment in AET can be derived, by assuming that welfare production regimes differ in terms of encouraging employees or firms to invest in AET (e.g. Dieckhoff et al. 2007, 84; Roosmaa and Saar 2010, 2012, Saar and Ure 2013; Saar et al. 2013).

Overall, a systematic pattern of AET-participation reflecting these regimes has not been identified. Regarding (un-)employment protection Brunello (2001, 11) finds training incidences being higher in countries with a higher index of employment protection whereas Bassanini et al. $(2005,115)$ find "On the one hand, the diffusion of temporary contracts reduce the investment in training; on the other hand, the reduction in the degree of employment protection for regular workers increases the provision of training." Concerning equality in access to AET Roosmaa and Saar $(2010,181 \mathrm{ff}$.) find that active labour market policies and a low level of employment protection legislation promote equality in access. For trade union coverage as an indicator for labour market regulation, several studies find high trade union coverage promoting the incidence of training (Brunello 2001, 11; Booth et al. 2003, 74ff. for the UK) as well as promoting equality in AETparticipation (Roosmaa and Saar 2010). Contrarily, Bassanini et al. (2005, 115f.) 
do not find an influence of union density on training in Europe. Reasons may be related to the fact that union coverage is quite diverse between sectors. Results by Dieckhoff et al. (2007, 88f.; 94) suggest that differences are rather located within branches than in welfare production regimes. Regarding the stratification of education systems results are inconsistent. Generally, training incidence is lower in countries with a high stratified education system (Roosmaa and Saar 2010, 193ff.). High levels of qualification within the population influence the incidence of AET positively (Brunello 2001, 11; Bassanini et al. 2005, 69f.; 77; 99f.) and low levels of formal qualifications are negatively associated with participation incidence (Roosmaa and Saar 2012, 498). Representing the demand side results strongly support that job related characteristics are central determinants for AET participation of individuals (e.g. Desjardins et al. 2006, 55ff.). Generally, high skill requirements and innovation indices promote AET participation (Bassanini et al. 2005, 68ff.; Roosmaa and Saar 2012, 495ff.). This corresponds to the result that innovation in companies influences companies AET provision positively (e.g. Schönfeld and Behringer 2013, 15) and companies experiencing labour and skill shortage tend to invest more in AET (Hughes et al. 2004 for Ireland).

Even though, theoretical approaches referred to often focus on the willingness to invest in AET of employees and employers being influenced by specific institutional packages (e.g. Roosmaa and Saar 2010, 2012; Boeren et al. 2010; Rubenson and Desjardins 2009) studies presented so far do not account for investment in AET for analysing participation patterns. The following section focuses on participation patterns in an international comparative perspective, taking into account different sources of investment for AET.

\subsection{Investment patterns in AET in international comparisons}

Who invests in AET? Generally, the major part of further education is at least partly paid by employers (e.g. Brunello et al. 2007; Desjardins et al. 2006; Desjardins and Rubenson 2011). FIBS and DIE (2013, 75ff.) include several data and information sources for estimating the distribution of state, employer and individual funding for adult education in selected countries. Results support that employers are the main investor in most countries. ${ }^{3}$ However, heterogeneous patterns on the amount of investment by other stakeholders are identified (ibid.). Overall, countries representing sociodemocratic welfare state regimes show higher state investment in AET. For other stakeholders no coherent pattern by welfare state resp. welfare production regimes is noticeable. But, indicators referred to do not allow differentiating e.g. states institutional or individual funding or vocational vs. non-vocational adult learning (ibid.).

Indicators used for identifying employer support in analyses based on individual data are quite diverse and comparable only to a limited extent. Desjardins et al. (2006, 55ff.) identify similar patterns for participating in AET overall and employer-sponsored AET. ${ }^{4}$ In general, results reveal the familiar pattern of privileged groups participating in AET; job tasks and reading

\footnotetext{
${ }^{3}$ Information on relations of funding volume for adult learning is included by referring to data of the AES 2007, CVTS4, information by national experts, statistical offices and/or ministries. Methodological issues are still present due to diverse sources of information and istinctions in different countries (FIBS and DIE 2013, 75ff.).

${ }^{4}$ Employer-sponsored AET is defined if direct or indirect expenses for AET participation are covered by the employer (Desjardins et al. 2006, 55ff.).
} 
competencies influence participation in employer-sponsored AET. Further analyses reveal that jobs skill content is even more important for predicting employersponsored AET-participation than educational attainment or literacy proficiency (Desjardins and Rubenson 2011, 25f.). ${ }^{5}$ Focusing on (mis)match between job tasks and skill level, results show that workers in high-skill matches are most likely to receive employer-sponsored AET, followed by employees in deficit situations, in surplus situations and least likely are those in low-skill matches. AET supported by state investment is nearly equally distributed between these groups. Self-financing AET is most likely for workers in high-skill matches and those in surplus situations. Differences between countries regarding inequalities for participating in employersponsored AET exist, but are not focused on (ibid., 55ff.).

Results by Brunello et al. (2007, 207-209) reveal similar patterns for employer-sponsored and training without a differentiation by investment. ${ }^{6}$ Nonetheless, some distinctions are striking comparing 'employer-sponsored training' and 'non-sponsored training' regarding the influence of gender, company size, contract and work time. Women are more likely than men to participate in 'all training' but less likely to participate in employer-sponsored AET. Employees in small enterprises "(..) pay more often (..) to compensate for the lack of employer support.” (ibid., 210). Similarly, workers in fixed term contracts and part-time work are less likely to participate in employer-sponsored and more likely to participate in non-employer-sponsored AET than full-time workers and those with permanent contracts. The influence of gender and company size is supported by data of the third Continuing Vocational Training Survey (CVTS3, 2005). In large companies women receive less often company sponsored training than men and employees in small firms less than those in large ones (Behringer and Schönfeld 2012, 29ff.). Analyses for Germany support the central influence of workplace characteristics (representing demand) on employer-sponsored AET participation as this is mainly affected by job tasks, job complexity and other firm related characteristics (Görlitz and Tamm 2011, 15ff. ${ }^{7}$; Kaufmann and Widany 2013, $\left.43 \mathrm{ff} .^{8}\right)$. Brunello et al. $(2007,212 \mathrm{ff} . ; 228)$ compare countries regarding the impact of determinants to participate in AET in general, not distinguishing different forms of investment. ${ }^{9}$ Overall, country effects are considerable and even stronger than those held by education, age, occupation, firm size and industry (ibid., 208ff.). Whereas these results support the assumptions of macro-level indicators determining (nation-specific) supply structures for AET, a systematic pattern is not identified.

\footnotetext{
${ }^{5}$ Employer-sponsored AET is defined if respondents received any financial support of employers. If financial support is received by government and no support by employers AET is defined as government financed. If respondents paid for AET participation without any financial support by employer or government, AET is categorized as self-financed (Desjardins and Rubenson 2011, 25f.).

${ }^{6}$ Employer-sponsored training is defined if it is being paid or provided by employers (Brunello et al. 2007, 218).

${ }^{7}$ Training carried out by the firm is defined as on-the-job training (ONJT), by another institution is defined as off-the-job training (OFFJT) (Görlitz and Tamm 2011, 4).

${ }^{8}$ Company-sponsored AET is defined as job related, taking place during working hours only and being free of charge or fully paid by employer (Kaufmann and Widany 2013, 40).

${ }^{9}$ In-depth analyses distinguishing employer-supported and non-employer supported AET are run with UK as reference country. Results are not interpreted regarding country differences (Brunello et al. 2007, 226ff.).
} 
Besides financial support time investment in AET is central to account for. Tuor Sartore and Backes-Gellner (2014, 94ff. for Germany) find, that employersponsored AET can be regarded as a non-wage component and by this, work release time is even more important than financial support for AET. In international comparison time constraints are reported to be the most important obstacle for AET participation, whereas lack of money is ranked fifth according to recent AES data (FIBS and DIE 2013, 100ff.). Further, analyses show that low educated workers are significantly less willing to invest time for AET than higher educated workers (Fourage et al. 2010 for The Netherlands). Hence, time investments are important to account for to strictly distinguish employer- and nonemployer-sponsored AET. Accounting for both, financial and time investment of employers and employees and distinguishing these distinctively Kaufmann and Widany (2013, 43ff. for Germany) differentiate purely company-sponsored and self-financed AET and a co-financed format of AET where employer and employee share financial and/or time investment. Of all job-related AET-cases $24 \%$ are accounted to this co-financed format that is usually not included in analyses on AET participation. ${ }^{10}$ By distinguishing these three formats, differences on determinants are revealed. In comparison, co-financed AET participation is less influenced by formal qualifications whereas workplace characteristics and the absence of an infrastructure for AET are important for engaging in co-financed AET. Further, solidly entrenched AET-infrastructures are crucial and more important than firm size or branch for the supply of fully company-sponsored AET and for reducing the need of individuals to compensate a lack of company support by self-financed AET (ibid.). This corresponds to findings based on CVTS2 data (1999) for Germany and Sweden where collective agreements on AET as well as public or AET-fond revenues influence employer-provided AET (Mytzek-Zühlke 2007, 226f.).

Overall, research supports that AET participation is conditional to opportunity structures and cross-country-differences exist, even if investment in AET is distinguished. Several macro-level characteristics are identified as relevant influence factors, but a systematic pattern of country specific constitutions has not been revealed. Overall, factors representing demand are of relevance whereas results on indicators representing the supply side are more inconsistent. Regarding investment in AET, time has so far not been included in international comparative analyses for differentiating AET by investment. Nor have co-financed formats of AET been considered where several parties (e.g. employers, employees, state) share investments. Generally, shared investment of different stakeholders exists in several European countries in heterogeneous compositions (Cedefop 2008, 3f.; 23ff.) and approaches prominently referred to stress the role of structural conditions for encouraging individuals and firms to invest in further education. Therefore, the relevant distinction of AET by investment is addressed empirically in the following sections.

\footnotetext{
${ }^{10}$ Percentages refer to activities including multiple participation. Share of companysupported AET is highest with $75 \%$ of the whole amount of job-related AET, $9 \%$ are fully self-financed. Participation rates in job related AET overall are 42,2 \%, splitting into $31,8 \%$ fully company-supported, 3,9 \% self-financed and 10,2 \% co-financed (Kaufmann and Widany 2013, 40).
} 


\section{Research question and theoretical assumptions}

In an initial step participation rates in AET differentiated by forms of investment in selected European countries are analysed against the theoretical backdrop of the VoC-approach (Estevez-Abé et al. 2001; Hall and Soskice 2001). Considering job related AET only, the following assumptions are derived. Countries classified as CMEs are likely to promote investment in AET by both, employers and employees. Due to high social protection, labour is not easy to dismiss for employers. In combination with product market strategies relying on (firm-/industry-) specific skills, which are related to constant investment in workforce training, employers are expected to invest in AET of their employees, as returns of training are expected to be higher than dismissing and recruiting new labour (Dieckhoff et al. 2007, 84). On the other hand, also employees are likely to invest in AET as employment protection is relatively high, securing such expenses. Furthermore, individual investment might lead to returns in terms of higher job positions within or by changing companies. Due to product market strategies relying on industry/occupational specific skills, job changes are expected to be relatively easy and not associated with a monetary or positional downturn for employees. Contrarily, in LMEs characterized by low social protection legislations, a general skill regime combined with product market strategies relying on general rather than specific qualifications, updating skills is expected to be necessary mainly for highly qualified workers resp. those in jobs with high skill requirements (ibid.). Yet, as employer-sponsored AET can be regarded as a non-wage component (Sartore et al. 2014) companies' investments in AET can be viable also for workers with lower qualifications. Therefore, sharing costs between employers and employees is assumingly worthwhile for both. AET solely financed by individuals is expected to occur in LMEs, too. Updating general skills is presumably not supported by employers so individuals have to invest in such training themselves. Assumingly countries classified as DMEs will show similar patterns as LMEs. In Mediterranean countries, characterized by medium social protection legislations, general skill formation systems and pronounced segmented labour markets, firms investment in AET of employers is likely to occur, but unevenly distributed in favour for those in internal labour markets (Dieckhoff et al. 2007, 86) . In France the established fonds-system for financing AET (e.g. Bosch 2010) might lead to a more equal distribution of access to employer-sponsored AET. Similar as for LMEs, shared investment of employers and employees is expected to occur in Mediterranean Countries, too. Completely individually financed training is expected to be less pronounced in Mediterranean countries, due to established internal labour market structures and in France due to the institutionalized fondsystem.

So overall, it is assumed that the amount of AET sponsored purely by companies as well as by individuals will be higher in CMEs than in LMEs and DMEs. Mediterranean Countries are expected to be in between these poles. Apart from the influence of labour market related regulations and characteristics of country-specific education and training systems, information on public support for individuals' participation in NFE is of interest. State support for individuals AET participation is expected to be more pronounced in countries classified as CME's and within these, more prominent in sociodemocratic welfare state regimes. Patterns of shared investment are primarily of exploratory interest. For investigating if this AET format is of relevance in other European countries and if 
different patterns can be related to welfare production regimes, countries are selected as follows. Representing CMEs Germany, Norway and Sweden are chosen. Whereas Germany is further characterised as corporatistic, Norway and Sweden represent a sociodemocratic welfare state regime. The UK represents a LME; Lithuania and Latvia stand for DMEs, France and Spain are included as examples for Mediterranean countries.

\section{Data base, sample selection and operationalisations}

Analyses are based on data of the Adult Education Survey (AES) 2011/12 that is conducted on an obligatory base in all European Member states, starting in 2011/12 (EC No. 452/2008; EU No. 823/2010). ${ }^{11}$ The cross-sectional survey is repeated every five years, covering a representative sample of individuals aged 25-64 in each country (EU No. 823/2010). Collecting information on adults' education participation, the AES refers to the Classification of learning activities (European Commission and Eurostat, 2006) Hence, information on formal education (FED), non-formal education (NFE) and informal learning (INF) are collected; reference period are the twelve months prior to the interview (European Commission and Eurostat 2014, 7). Main distinctive criterion of FED and NFE is the acknowledgement within the national qualification framework (NFQ, European Commission and Eurostat 2012, 4ff.). For answering the research question, only non-formal education (NFE) activities that have been done for job related reasons are referred to. ${ }^{12}$ By this, the recommendation by some researchers not to differentiate FED and NFE in international comparative analyses (Behringer and Schönfeld 2014, 385; Behringer et al. 2013, 333f.) is not followed. Their main argument refers to differences between countries acknowledging learning activities in the NFQ. By this, identical learning activities might be classified as FED in one country and as NFE in another (ibid.). Reasons for not following this recommendation are that (1) information whether the learning activity was jobrelated is not collected for FED, (2) analyses based on an activity dataset focusing on differences of participation and investment patterns by distinguishing and combining formal and non-formal education (Reichart and Kaufmann 2015) suggest that diverse structures between FED and NFE exist, especially regarding finance patterns. If FED and NFE are combined, these differences would be missed. The sample is restricted to the working population aged 25-64, excluding family workers and those who currently participate in formal education (FED). Sample sizes for the selected countries are displayed in table 1 .

\footnotetext{
${ }^{11}$ Data used in this contribution are provided by Eurostat, Unit B-1. Access is granted to the microdata set Adult Education Survey (AES) according to the research proposal no. 69/2014-AES.

${ }^{12}$ Information of 1st and 2nd NFE activity is included. Some countries collect information on more than two NFE-activities but not all countries included in this paper (European Commission and Eurostat 2014, 29).
} 


\section{Table 1 Sample sizes for selected countries}

\begin{tabular}{|c|c|c|c|c|c|c|c|c|}
\hline $\begin{array}{l}\text { Welfare } \\
\text { produc- } \\
\text { tion }\end{array}$ & \multicolumn{2}{|c|}{ CME } & \multirow{2}{*}{$\begin{array}{c}\text { CME } \\
\begin{array}{c}\text { Ger- } \\
\text { many }\end{array}\end{array}$} & \multicolumn{2}{|c|}{$\begin{array}{l}\text { Mediterranean } \\
\text { Countries }\end{array}$} & \multicolumn{2}{|c|}{ DME } & \multirow{2}{*}{$\begin{array}{c}\text { LME } \\
\text { UK }\end{array}$} \\
\hline Country & $\begin{array}{l}\text { Nor- } \\
\text { way }\end{array}$ & $\begin{array}{l}\text { Swe- } \\
\text { den }\end{array}$ & & Spain & France & $\begin{array}{l}\text { Lithua- } \\
\text { nia }\end{array}$ & $\begin{array}{c}\text { Lat- } \\
\text { via }\end{array}$ & \\
\hline $\begin{array}{l}\mathbf{N}- \\
\text { unweighte } \\
\text { d data }\end{array}$ & 2195 & 2470 & 4190 & 9535 & 9614 & 2741 & 3386 & 2163 \\
\hline $\begin{array}{l}\mathbf{N}- \\
\text { weighted } \\
\text { data }\end{array}$ & $\begin{array}{c}2.080 . \\
454\end{array}$ & $\begin{array}{c}3.875 . \\
033\end{array}$ & 32.059 .626 & $\begin{array}{c}15.970 . \\
988\end{array}$ & $\begin{array}{c}24.976 . \\
113\end{array}$ & $\begin{array}{c}1.151 . \\
194\end{array}$ & $\begin{array}{c}833.79 \\
7\end{array}$ & $\begin{array}{c}21.465 . \\
838\end{array}$ \\
\hline
\end{tabular}

Note. Norway and Sweden can be regarded as representatives of sociodemocratic welfare state regimes, Germany, Spain and France as representatives of conservative/corporatistic welfare state regimes. Source: AES 2011/2012, SUF, own calculations.

Participation rates vary between countries, displaying more or less the familiar pattern of countries with high participation rates in the Nordic countries and lower rates in Lithuania and Latvia. Further, NFE participation is mainly job related in all countries.

Primarily following Kaufmann and Widany (2013) information on financial and time investment of employers and individuals in job related NFE is used to distinguish company-sponsored and self-financed NFE distinctively. Accordingly, 'company-sponsored NFE' is defined as being fully financed by the company or free of cost for the participant and taking place during working hours only. 'Selffinanced NFE' is paid fully by the participant and taking place outside working hours only. Shared investment between employers and employees for NFE either by time or money is considered in the 'co-financed-employer-individual NFE' format. Due to limited cases numbers NFE financed purely by state support cannot be distinguished. However, there are a considerable number of NFE incidents characterised by a combination of investment by employer, individual and public employment services or other public institutions for NFE. These constitute an own format termed 'co-financed pooled-employer-individual-state' NFE. Table 2 summarizes the classification criteria according to financial and time investments. 
Table 2 Classification of NFE-activities by financial and time investments of employers, employees and state

\begin{tabular}{|c|c|c|c|}
\hline \multicolumn{4}{|c|}{ NFE participation for job related reasons } \\
\hline $\begin{array}{l}\text { Company- } \\
\text { sponsored }\end{array}$ & Self-financed & $\begin{array}{l}\text { Co-financed- } \\
\text { employer- } \\
\text { individual }\end{array}$ & $\begin{array}{l}\text { Co-financed-pooled- } \\
\text { employer-individual- } \\
\text { state }\end{array}$ \\
\hline $\begin{array}{l}\text { costs fully paid by } \\
\text { employer OR free of } \\
\text { charge }\end{array}$ & $\begin{array}{l}\text { costs fully paid by } \\
\text { individual OR free } \\
\text { of charge }\end{array}$ & $\begin{array}{l}\text { costs paid by } \\
\text { employer AND by } \\
\text { individual }\end{array}$ & $\begin{array}{l}\text { costs paid by employer } \\
\text { AND individual AND } \\
\text { public employment services } \\
\text { or other public institutions }\end{array}$ \\
\hline $\begin{array}{l}\text { AND fully during } \\
\text { working hours }\end{array}$ & \multirow[b]{2}{*}{$\begin{array}{l}\text { AND fully outside } \\
\text { working hours }\end{array}$} & \multirow[b]{2}{*}{$\begin{array}{l}\text { during or outside } \\
\text { working hours }\end{array}$} & \multirow[b]{2}{*}{$\begin{array}{l}\text { during or outside working } \\
\text { hours }\end{array}$} \\
\hline $\begin{array}{c}\text { OR } \\
\text { Guided on the job } \\
\text { training* }\end{array}$ & & & \\
\hline
\end{tabular}

Note. *In AES 2011/2012 'Guided on the job training' is collected as a format of NFE and by definition it is assumed that this takes place during working hours only (European Commission and Eurostat 2012, 6ff.; 35f.; European Commission and Eurostat 2013, 28ff.).

\section{Results}

\subsection{Descriptives}

According to the above specified classifications only cases holding valid information on the purpose (job related/not job related) and on financial and time investment for NFE are included. By this, Sweden and the UK reveal a high number of missings; the other countries show negligible missing values in the relevant variables. Including information of first and second NFE activity, participation rates for the differentiated formats in the selected countries show that purely company-sponsored NFE is the most prominent format (figure 1).

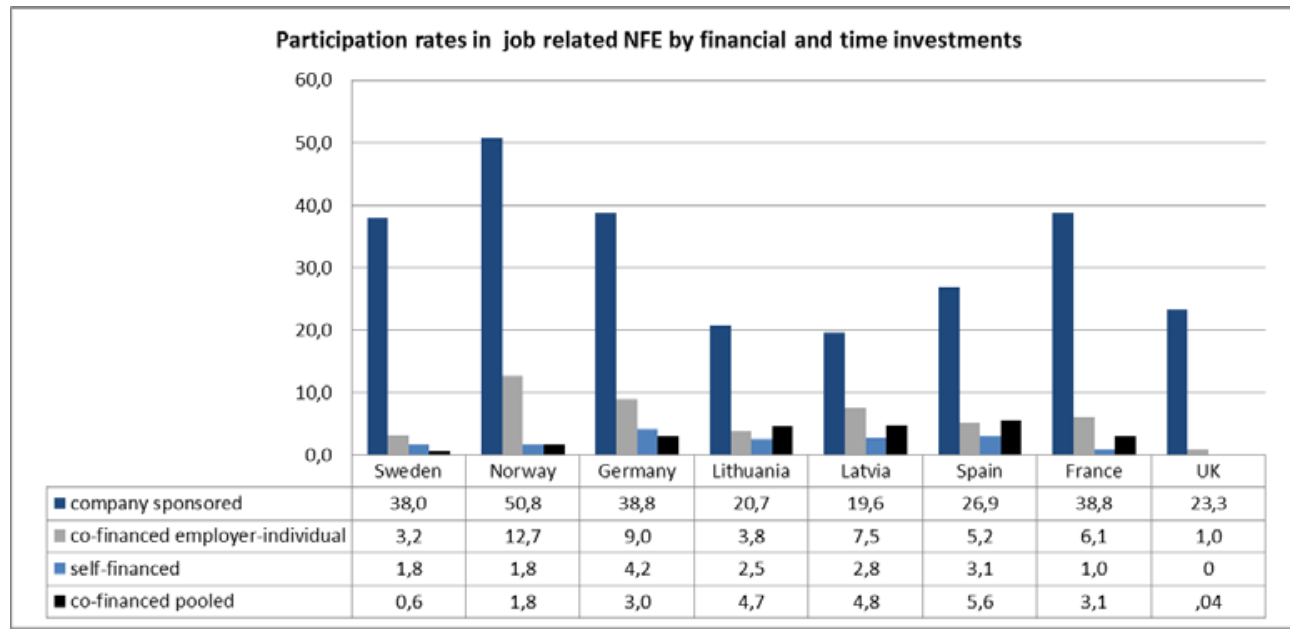

Figure 1 Participation rates in job related NFE (1st and 2nd) distinguished by financial and time investments of employers, individuals and state. Source: AES 2011/2012 SUF, weighted data; own calculations.

The pattern follows previous results of highest rates in CME countries, lowest in DMEs and Spain as a Mediterranean country in between. Regarding differences in 
the amount of purely company-sponsored NFE results are generally in line with theoretical assumptions of cross-country differences in relation to welfareproduction regimes. However, participation in purely company-sponsored NFE in France is as high as in Germany, probably reflecting the established fond concept in France, where companies are obliged to invest a certain amount of their total payroll in an AET-fond (Cedefop 2008, 81ff.). Self-financing NFE is hardly prevailed and only partly supporting theoretical assumptions according to welfare production regimes. Highest rates in Germany (4.2 \%) as a CME and in the Baltic States representing DMEs were expected. Yet, self-financing NFE in Spain as a Mediterranean country with pronounced internal labor markets was unexpected but could be related to the recent financial crisis. Also unexpected is identifying any case of self-financed NFE in the UK, representing a LME. The latter result is startling but as information is missing in so many cases in the UK and in Sweden results should be interpreted only cautiously. Referring to the abovementioned concerns that learning activities might be classified differently in various countries, analyses were conducted for FED, too. Yet again, no cases of self-financed AET were identified for the UK. The estimations by FIBS and DIE (2013, 75ff.) reveal results as theoretically expected for the UK. Similarities to the descriptives presented occur regarding individual investments in AET being more prominent in Germany and Spain (ibid., 78). Interestingly, for Norway results are more diverse as FIBS and DIE (ibid.) identify a relatively small amount of employer and individual investment and a high amount of state funding, the latter corresponding strongly to theoretical assumptions of welfare state regimes.

Overall, descriptive results suggest, that shared investment in NFE is relatively prevailed in all selected countries. Employers and employees investing together in NFE (co-financed employer-individual) is common with highest rates in Norway and Germany. Overall, the theoretically expected pattern is supported but for the relatively high amount of co-financed-employer-individual NFE in Latvia. The co-financed pooled NFE format, where the investment is shared between companies, individuals and public authorities is surprisingly widespread in Spain, Latvia and Lithuania, followed then by Germany and France. Referring to assumptions by the VoC-approach, results are unexpected especially for the Baltic States. This might reflect the fact that a large share of funding is provided by EU and ESF programs in these countries (e.g. GHK and Research voor Beleid 2011a, 2011b; Cedefop 2012a, 2012b). As co-financed formats of NFE have not been investigated in an international comparative perspective so far, results indicate that these formats are common in several European countries, however, not consistently following a theoretically expected pattern. Whether the distinction of these NFE formats is relevant also in terms of determinants for participation is investigated in the following section.

\subsection{Multivariate results}

For analysing participation patterns in the distinguished NFE formats logistic regressions are conducted where participation in the respective format constitutes the dependent variable. Estimations are carried out separately for the selected countries. As a high amount of information is missing for Sweden and the UK these are excluded from further analyses. Due to limited case numbers in some NFE formats for Lithuania and Latvia data for these countries are pooled, since both represent DMEs and overall show similar participation rates. Considering case numbers, estimations for self-financed AET are carried out for Germany, the Baltic 
States and Spain only. ${ }^{13}$ Again, due to limited case numbers Norway has to be excluded from analyses for the co-financed pooled format. In terms of theoretical implications countries included still cover all welfare production regime classifications.

Independent variables are selected according to the state of research and theoretical assumptions of influence factors representing supply and demand for participating in NFE. Accordingly, individual related characteristics as age, gender and formal qualification grades are included. Job related variables representing demand aspects are enclosed covering occupational classification, firm size, type of contract, duration of employment within the current company and full- vs. parttime work. Due to limited case numbers, branch indicators cannot be controlled for and categorizations of several variables had to be conflated. Results of logistic regression estimations are displayed as odds ratios. Regarding the effect size odds ratios are often interpreted in a misleading way and can be compared only in terms of direction (increase/decrease) and significance of effects across models and samples but not in terms of the amount of in-/decrease. Therefore, logistic regressions are additionally estimated based on a pooled dataset for all countries, controlling for country effects. Based on these results, mean predicted probabilities for selected independent variables on the dependent variable (participating in the respective NFE format) are plotted, differentiated by countries (Best and Wolf 2010, 832f.; Bauer 2010, 917ff.).

Overall, estimations for company-sponsored NFE reflect the state of research of individual and job related characteristics influencing participation. Model fit indicators suggest a reasonable fit for all countries for explaining participation in purely company-sponsored NFE; slightly better for Germany, the Baltic States and France than for Norway and Spain (tab. 3). For self-financed NFE indicators suggest a reasonable model fit for the Baltic States but a better fit for Germany and Spain (tab. 6). For the co-financed formats model fit indicators are generally not as good as for the company-sponsored NFE format, but apart from Norway, overall reasonable (tab. 4, 5). For explaining participation in co-financed pooled NFE model fit parameters are quite similar to the co-financed employer-employee format, apart from Spain. Here, indicators suggest a better model fit for the cofinanced-pooled format. Generally, these results suggest that relevant determinants for explaining participation in the co-financed NFE formats are not yet included and require further investigation.

Regarding age, the pattern for purely company-sponsored NFE is quite similar across countries. Compared to the age group of 35-44 year olds, people aged 55 and above are less likely to participate in company-sponsored NFE but the two Baltic States. As former results are not consistent regarding age and trend analyses suggest that AET participation of older workers overall increased (e.g. Riphahn and Trübswetter 2007; Schiener 2006; Seifried and Berger 2011) this result seems to confirm the investment logic of employers to invest primarily in younger employees. This is underlined by the fact that increasing age is not consistent for influencing participation in the co-financed NFE formats. Only in the Mediterranean countries workers aged 55 and older are less likely than 35-44 year olds to participate in co-financed employer-individual NFE whereas in the remaining countries no significant age effect is identified. This result might reflect pronounced internal labour markets combined with a general skill formation

${ }^{13}$ Number of observations should be at least 100 (Best and Wolf 2010, 837). 
system in the Mediterranean countries, affording (shared) investment in AET by the time entering the labour market (e.g. Gangl 2003; Brzinsky-Fay 2007). For Spain, this is supported by the fact that workers aged 45-54 are less likely to invest in NFE themselves compared to those aged 35-44. In the remaining countries, selffinanced NFE is not influenced by age. Regarding co-financed-pooled NFE workers aged 45-54 are more likely than 35-44 year olds to participate in Spain and in Germany. Presumably, specific funding instruments for this age group are of relevance in these countries. Overall, gender related participation patterns for NFE distinguished by investment support former results of women being less likely to participate in company-sponsored NFE and being more prone to cover at least some investment by themselves (e.g. Brunello et al. 2007; Kaufmann and Widany 2013). Regarding country differences only results for company-sponsored NFE can be related to the theoretical differentiations of countries as only in Norway and Germany, representing CMEs with high social protection and (firm-/industry-) specific product market strategies, no significant gender differences occur. But contrasting, women in Germany are more likely to self-finance NFE or to share the investment with their employer. Regarding co-financed formats being female is associated with higher participation probabilities also in France for co-financed employer-individual, and in the Baltic States for co-financed pooled NFE. As interpretation in relation to welfare production regimes is less intuitive, results rather suggest that the disadvantage for women to participate in companysponsored NFE in the Baltic States is compensated by state involvement.

In all investigated countries the relevance of formal qualifications and occupational classifications for participation in purely company-sponsored NFE is noticeable with some interesting exceptions in some parameter characteristics. Formal qualification grades show the familiar pattern in all investigated countries, but in the Baltic States, where no differences between low educated and workers with higher education can be observed for participating in company-sponsored NFE. But this might be due to smaller case numbers in this category in these countries. Further, in Norway, Germany and France, no significant differences are observed between low skilled nonmanual and high skilled nonmanual occupational classifications for participating in company-sponsored training. This indicates, that occupational related aspects such as nonmanual job tasks (representing demand for AET) are the relevant aspect for companies' decisions to invest in training whereas the level of qualification (representing supply) seems to be of less relevance in these countries. Regarding expected patterns according to the VoC-approach, these results might reflect the pronounced social protection combined with mainly (firm/industry-) specific skill-requirement and -supply patterns in Norway and Germany, making it profitable to invest also in workers in jobs with lower skill affordance. As for France, the pattern might reflect the obligatory fond-system for NFE for firms as mentioned. For self-financed NFE results suggest reduced probabilities for those with lower qualifications and lower occupational classifications in all countries. Plotted mean probabilities within each country suggest for all countries a rather small impact of these parameters for self-financed NFE (not displayed). 
Table 3 Estimation results of logistic regressions for participation in companysponsored NFE

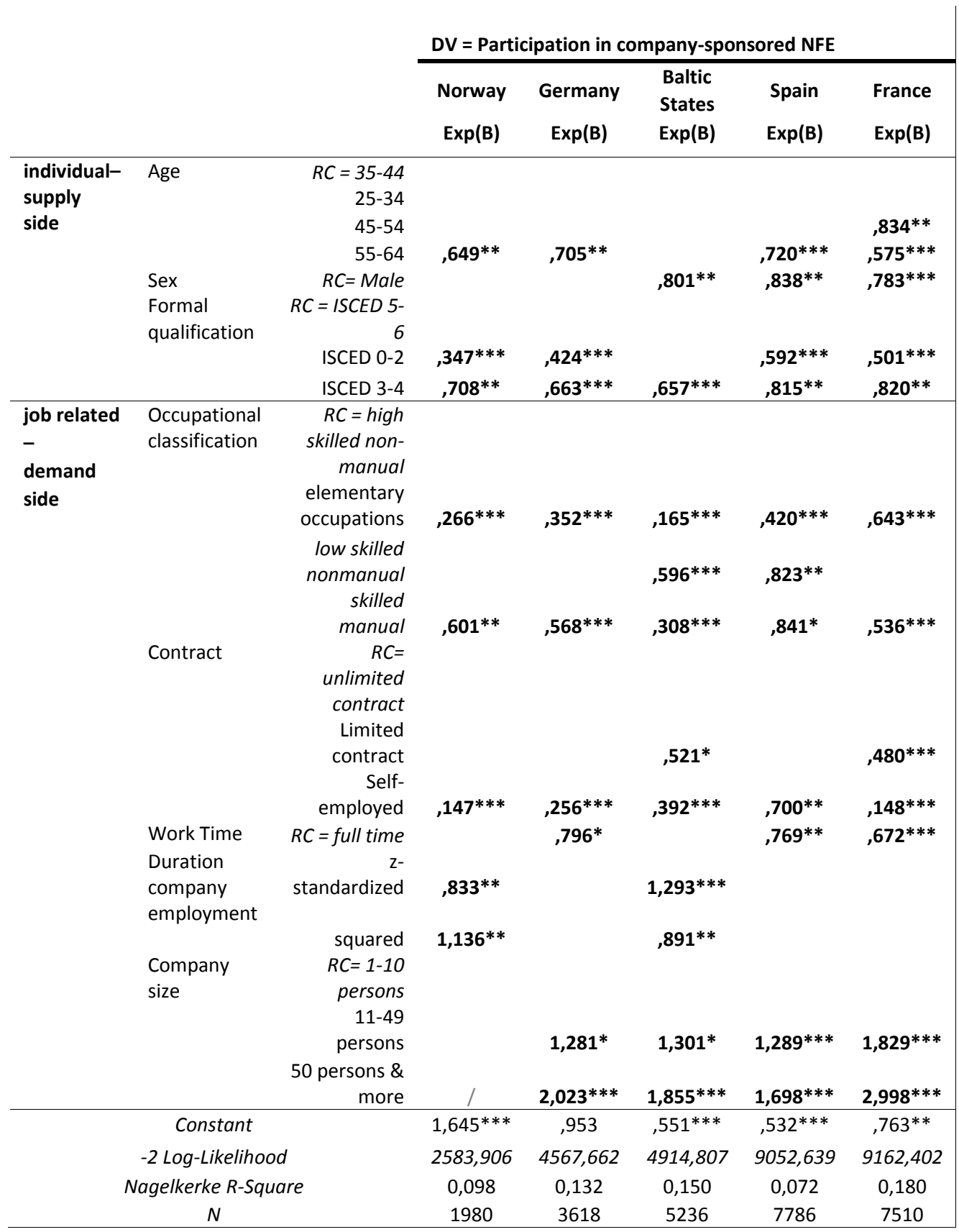

Note. Significant results displayed only. ${ }^{*} \mathrm{p}<0.050$; ${ }^{* *} \mathrm{p}<0.010$; ${ }^{* * *} \mathrm{p}<0.001$. Source: AES 2011/2012 SUF, unweighted data, own calculations. 
Table 4 Estimation results of logistic regressions for participation in cofinanced NFE - employer-individual

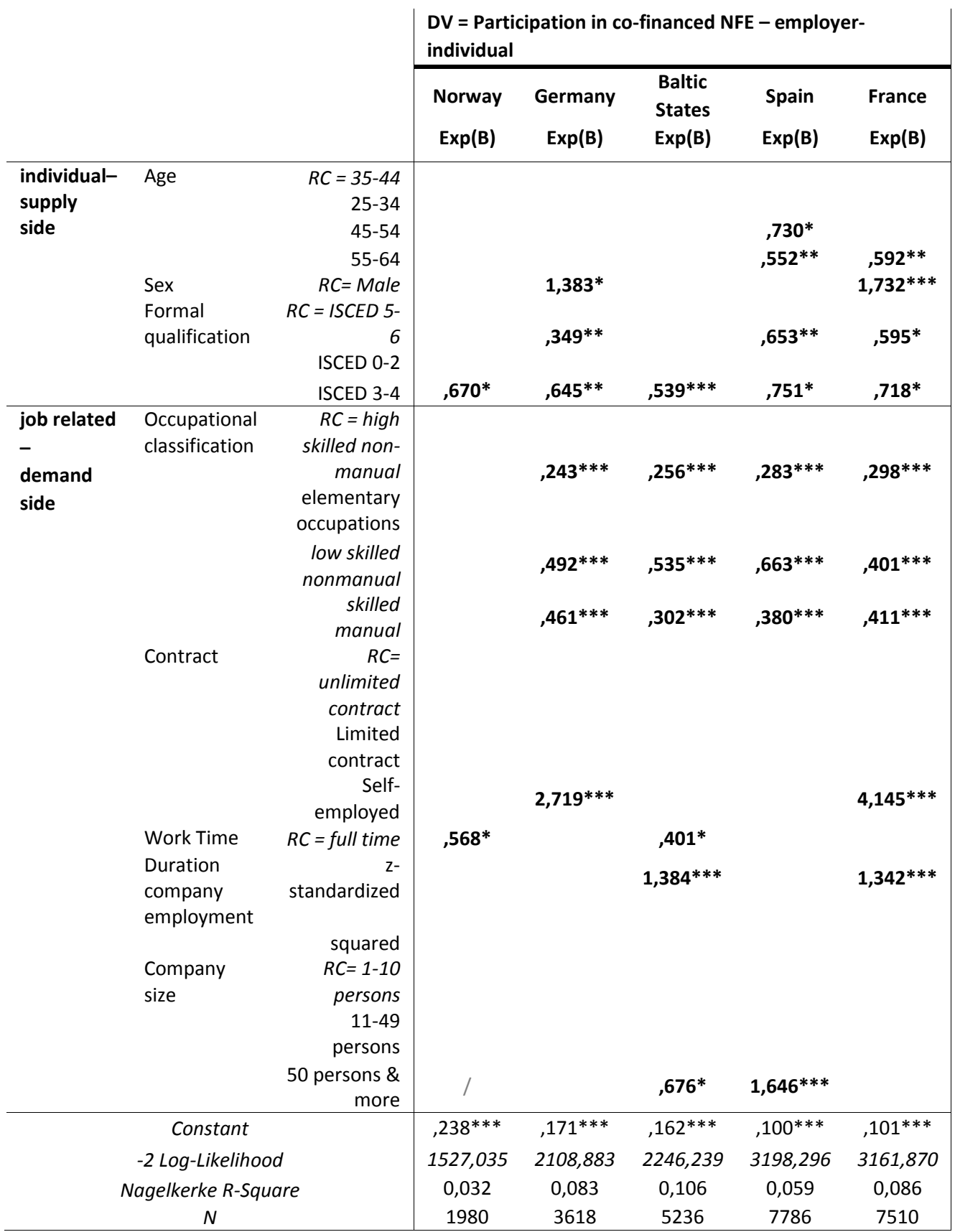

Note. Significant results displayed only. ${ }^{*} \mathrm{p}<0.050$; ${ }^{* *} \mathrm{p}<0.010$; ${ }^{* * *} \mathrm{p}<0.001$. Source: AES 2011/2012 SUF, unweighted data, own calculations. 
Table 5 Estimation results of logistic regressions for participation in cofinanced-pooled-employer-individual-state NFE

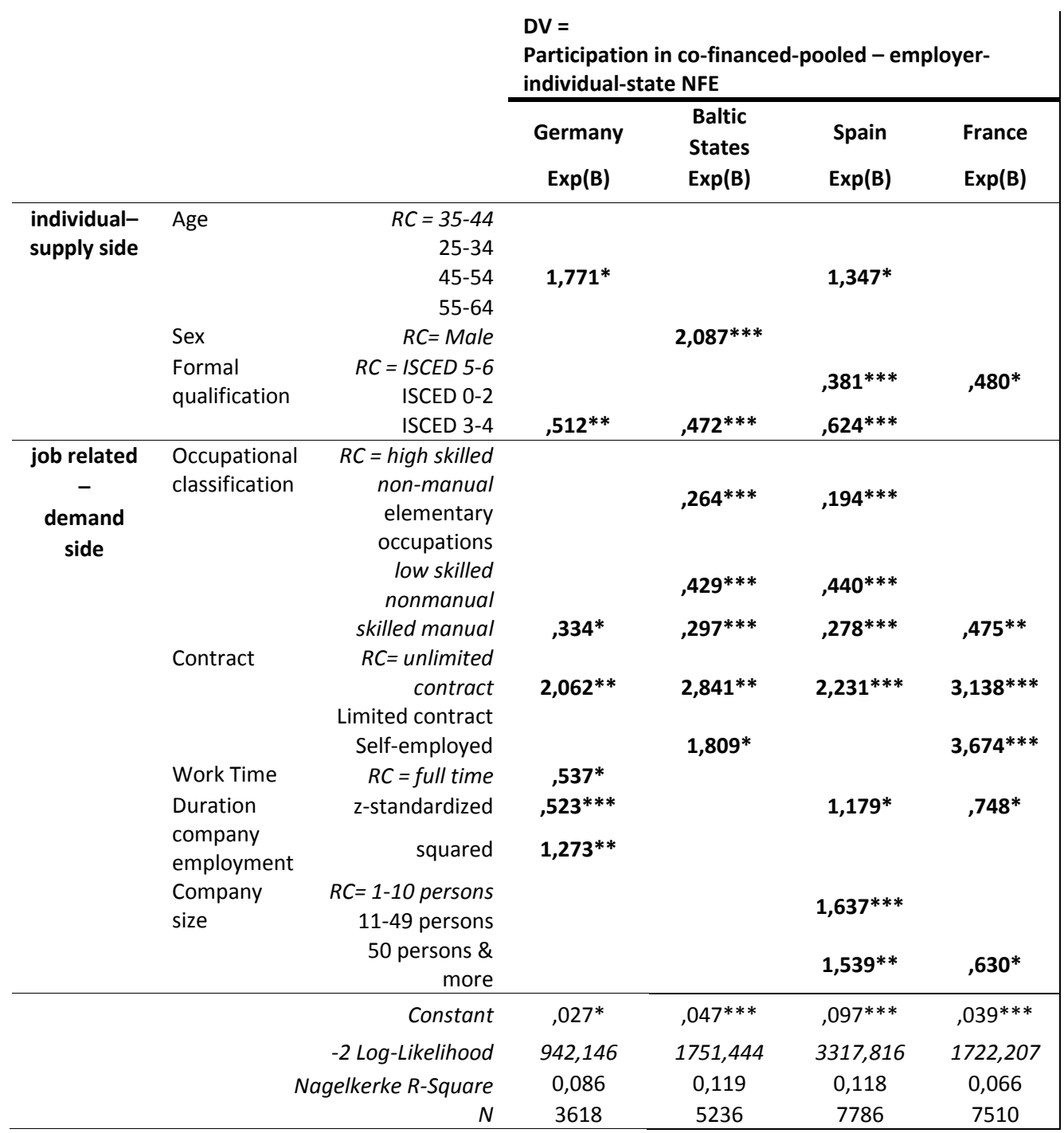

Note. Significant results displayed only. ${ }^{*} \mathrm{p}<0.050 ;{ }^{* *} \mathrm{p}<0.010 ;{ }^{* * *} \mathrm{p}<0.001$. Due to limited case numbers Norway had to be excluded from estimations for co-financed-pooledemployer-individual-state NFE. Source: AES 2011/2012 SUF, unweighted data; own calculations. 
Table 6 Estimation results of logistic regressions for participation in selffinanced NFE

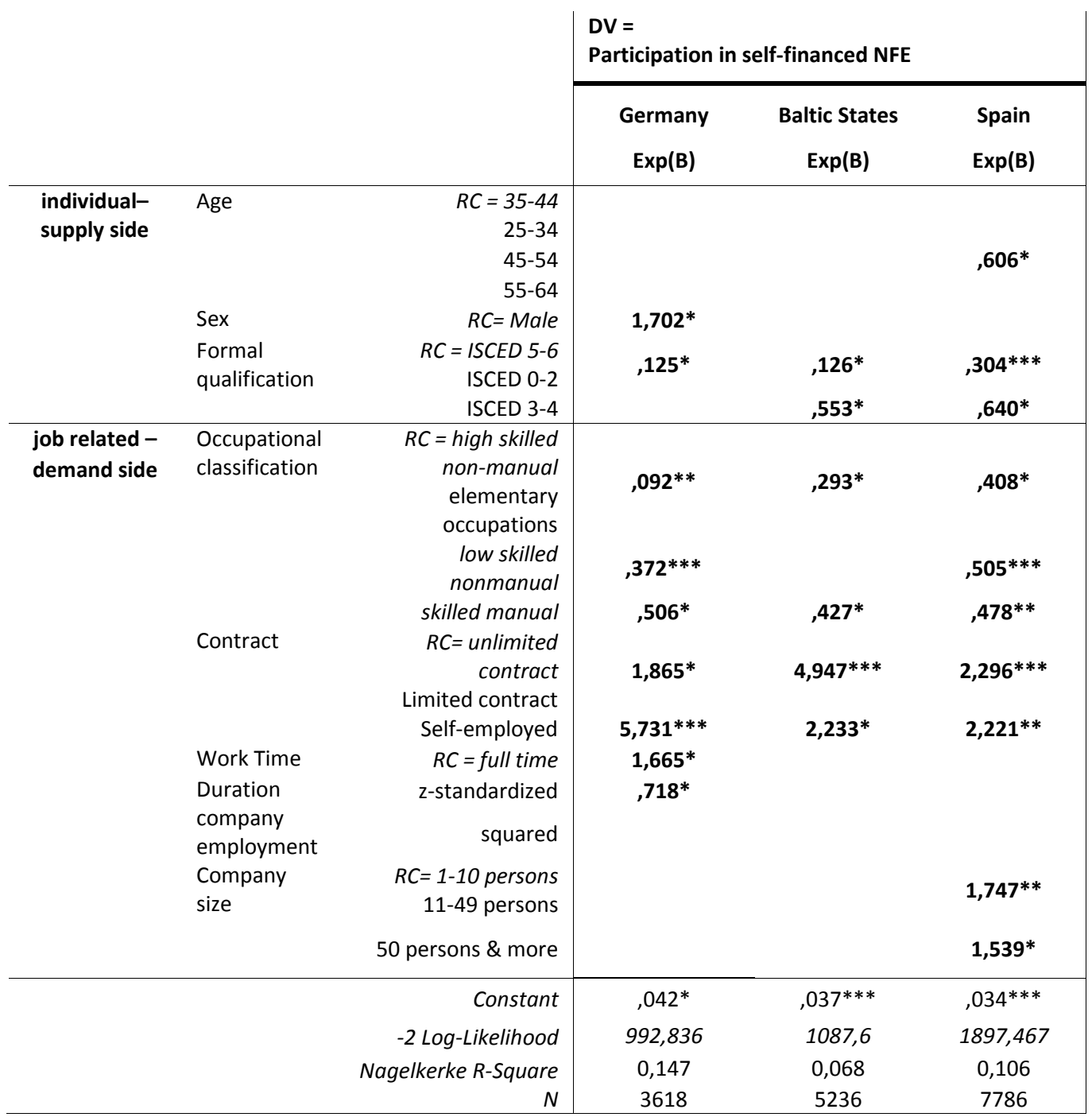

Note. Significant results displayed only. ${ }^{*} \mathrm{p}<0.050$; ${ }^{* *} \mathrm{p}<0.010 ;{ }^{* * *} \mathrm{p}<0.001$. Due to limited case numbers Norway and France had to be excluded from estimations for self-financed NFE. Source: AES 2011/2012 SUF, unweighted data, own calculations.

Comparing these results to the co-financed NFE formats some differences arise. For all countries but Norway a very similar pattern regarding the influence of formal qualifications and occupational classifications as for participation in purely company-sponsored NFE is identified for co-financed-employer-individual NFE. For Norway, results suggest that relevant determinants are missing. As this NFE format is comparably wide spread in Norway this result is at least unexpected. For co-financed-pooled NFE, where investment of the state is involved, too, in all countries but Germany and France medium qualifications and lower occupational positions are negatively associated with participation. In terms of country differences, patterns can only cautiously be related to welfare production regimes. E.g. the result that workers in elementary and low-skilled nonmanual occupational job positions are not less likely to participate in co-financed-pooled NFE than those 
in high skilled non-manual positions in Germany and France suggest that public funding initiatives outweigh lack of pure employer support which could cautiously be related to both countries representing corporatistic welfare state regimes.

Turning towards other job related characteristics influencing NFE participation findings for purely company-sponsored NFE reflect previous results of higher probabilities for employees in larger companies, but Norway. ${ }^{14}$ For the co-financed formats the influence of company size is different with some opposing effects between countries. Apart from Spain and the Baltic States, firm size is of no relevance for participation in co-financed employer-individual NFE. The pattern for the Baltic States, where skill formation systems provide rather generally educated workers, simply suggests that shared investment in AET outweighs the difficulties of smaller firms to provide fully company-sponsored NFE. As for Spain, employees in bigger firms are more likely to participate in NFE, no matter whether the investment is shared between employers and individuals or additionally being sup-ported by the state, supposing to reflect the pronounced internal labour market structures. Regarding shared investment in NFE by employers, individuals and the state results for France show that workers in large firms are less likely to participate than those working in small companies. Again, this pattern suggests that public support compensates for lack of employer support in small companies in France.

In all countries self-employed are less likely to participate in purely companysponsored NFE and more likely to participate in one of the co-financed NFE formats. As the distinction of spending private time and money for NFE is presumably easier for employed than self-employed, the result might just reflect differences in classifying financial and time investments. But in France and in the Baltic States self-employed are more likely to participate in co-financed pooled NFE than those with permanent contracts, suggesting the existence of specific funding instruments for self-employed for NFE in these countries; a relation to welfare production regimes can hardly be made. Similarly, workers with limited contracts are more prone to participate in co-financed pooled NFE than those with unlimited contracts in all countries. Whereas in Norway, Germany and Spain differences only exist between self-employed and employees with permanent contracts, workers with limited contracts in France and the Baltic States are less likely to receive company-sponsored NFE than those in permanent positions. For CME countries this pattern supports theoretical assumptions as product market strategies relying on specific skills constantly afford regular skill refreshment. For France the result supports investment logics of employers in strong internal labour markets, whereas for the Baltic States the result could just reflect firms' general investment logics for AET in workers with highest returns anticipated. Further, workers with limited contracts are more likely to self-finance NFE in Germany, Spain and the Baltic States. Overall, these results go in line with assumptions according to welfare production regimes. In CMEs self-investment is likely to yield returns in terms of better job positions within or by changing companies. In the Baltic States workers in limited positions might just have to outweigh lack of company-support which is also relevant in Spain with strong internal labour markets.

\footnotetext{
${ }^{14}$ The data for Norway provide any cases for firm size with 50 or more employees. For the remaining categories of 1 to 10 and 11 to 49 employees no differences for NFE participation are observed.
} 
Working part-time is negatively associated with participation in companysponsored NFE in Germany, Spain and France. This negative relation of part-time work is also observed for co-financed-employer-individual NFE in the Baltic States and Norway. Positively associated is part-time work with self-financed NFE in Germany. Finally, duration of employment in the current company is of mixed results for explaining participation in the diverse formats and countries. For company-sponsored NFE a significant influence is identified only for Norway and the Baltic States, but indicating opposite effects: In Norway firms seem to invest especially in the first years of employment in their employees, suggesting to smooth integration into the position whereas in the Baltic States the investment of firms obviously focuses more on updating skills of employees with a longer duration within the company. According to theoretical assumptions, however, this result is contradictory to expected patterns.

For getting an idea about the impact of selected parameters on participation in the NFE-formats, mean predicted probabilities based on results of logistic regressions with pooled data covering all countries are plotted for selected parameters, distinguished by countries (fig. 2, 3). For company-sponsored NFE results show a similar pattern in all countries, indicating the strongest impact of highly skilled non-manual occupations that seem most pronounced in Norway and Germany than the remaining countries. This pattern is also valid for co-financed employer-individual NFE. Predicting participation in co-financed-pooled NFE occupational classification is most relevant in Spain. For all countries and all NFEformats factors representing demand for AET (occupational classification) seem of higher relevance for predicting participation than those of supply (formal qualification, not displayed). 


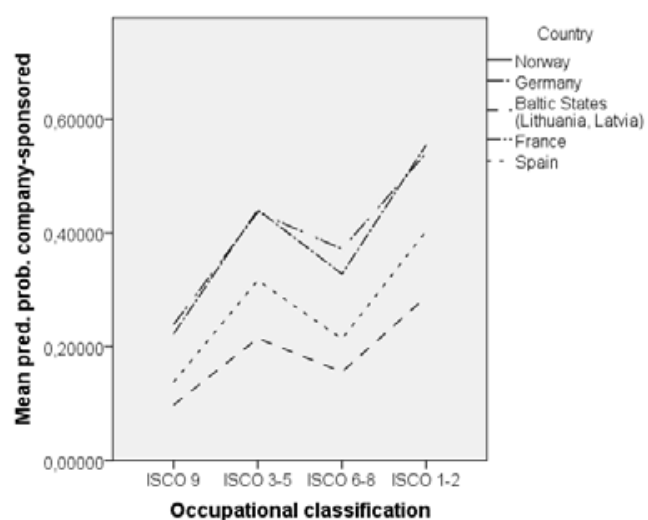

a) company-sponsored NFE

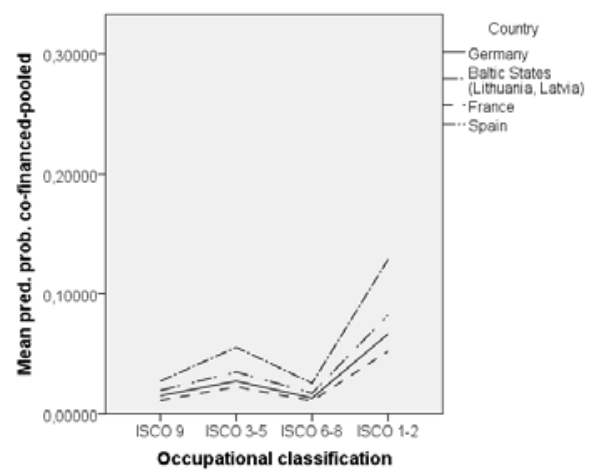

c) co-financed pooled NFE

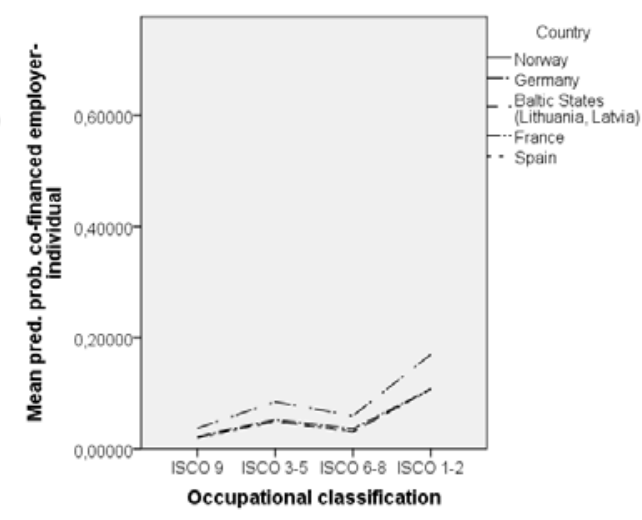

b) co-financed (employer-individual) NFE

Figure 2 Predicted probabilities for participation in a) company-sponsored NFE, b) co-financed (employer-individual) NFE and c) co-financed pooled NFE of occupational classification in Norway, Germany, the Baltic States, France and Spain. Source: AES 2011/2012 SUF, unweighted data; own calculations.

Regarding company size, predicted probabilities suggest a stronger influence for participation in company-sponsored NFE in Germany and France and smallest in the Baltic States. For all countries, the relatively small impact of company size for predicting participation in the co-financed NFE formats is visible (fig. 3). Yet again, for co-financed-employer-individual NFE influence of company size seems more pronounced in Norway and Germany. Contrarily, for co-financed pooled NFE influence of company size is most pronounced in Spain, lowest in Germany and France. These results overall support the above suggested interpretations with reference to the VoC-approach. 


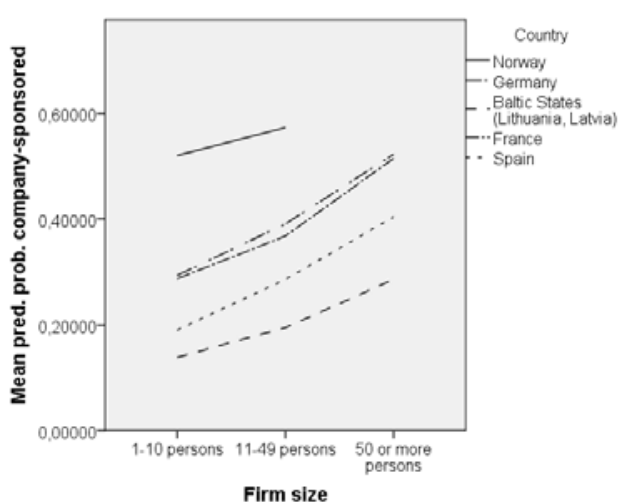

a) company-sponsored NFE

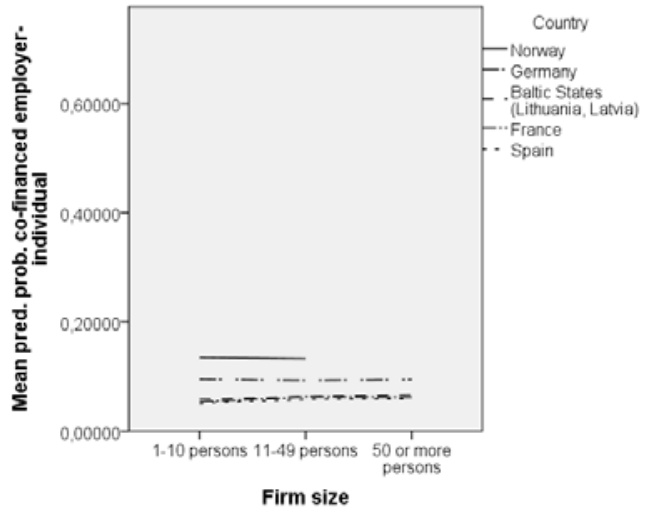

b) co-financed (employer-individual) NFE

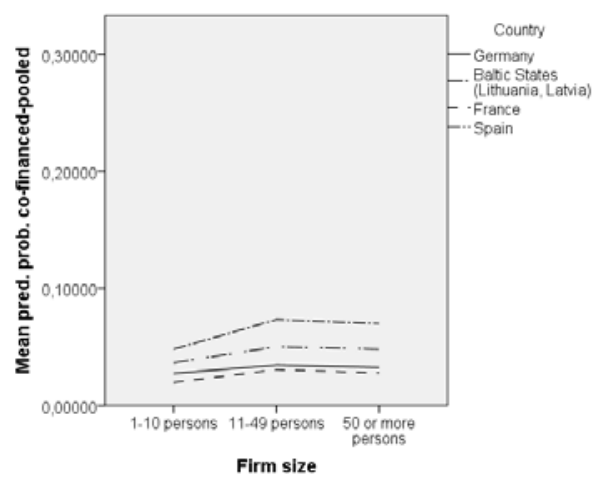

c) co-financed pooled NFE

Figure 3 Predicted probabilities for participation in a) company-sponsored NFE, b) co-financed (employer-individual) NFE and c) co-financed pooled NFE of firm size in Norway, Germany, the Baltic States, France and Spain. Source: AES 2011/2012 SUF, unweighted data; own calculations. Note. Regarding missing data for Norway: Norway provide any cases for firm size with 50 or more employees. For the remaining categories of 1 to 10 and 11 to 49 employees no differences for NFE participation are observed. Due to limited case numbers Norway was excluded from estimations for co-financed-pooled NFE.

\section{Discussion}

Analyses on investment and participation patterns in selected European countries support that the major part of job related NFE is purely sponsored by employers, also if time is considered as an additional source of investment. Contrarily, pure individual investment in NFE is rare across countries. Prevailed in all countries are co-financed NFE formats. Results reveal not only the quantitative relevance but also different participation patterns for co-financed NFE formats compared to fully company-sponsored or self-financed NFE and between countries. Even though determinants included explain best participation in company-sponsored NFE, 
results emphasize the relevance to distinguish investment in AET distinctively and taking monetary and time investments into consideration.

With reference to the VoC-approach, assumptions were derived regarding country-specific investment patterns in NFE by companies, individuals and the state. Results partly support theoretically expected patterns with highest rates of company-sponsored NFE in CMEs and lowest in LMEs and DMEs. Further, the relatively high amount of shared investment in NFE in CMEs was expected. But, identifying any case of self-financed NFE in the UK and relatively high rates of cofinanced pooled NFE in Latvia and Lithuania is unexpected. The result for the Baltic States might mirror a large share of NFE being project based and externally funded by EU programs (e.g. GHK and Research voor Beleid 2011a, 2011b). Determinants for participation are different between NFE formats and countries, however going only partly in line with theoretical assumptions according to the VoC-approach. Generally, cross-country differences are more pronounced for cofinanced formats and self-financed NFE than for purely company-sponsored NFE. For the latter, differences between countries are mainly identified for specific categories of parameters (e.g. for nonmanual occupational activities) but less often for whole parameters being (not) identified as relevant influence factors. By this, previous results are mainly supported, revealing the strong influence of formal qualifications, occupational classifications, company size and full- vs. part-time work, reflecting the interplay of supply and demand factors for explaining company-sponsored NFE participation. Even though, differences are detected regarding the effects of certain influencing factors and model fit indicators between countries, patterns are generally very similar for participation in companysponsored NFE across countries. Model fit indicators reveal the relatively small impact of parameters included for explaining participation in NFE formats that are not fully sponsored by employers in all countries. This suggests that relevant parameters are associated with participation in the co-financed NFE formats that are not controlled for. Nevertheless, different participation patterns for the diverse NFE formats emphasize the necessity to distinguish NFE by investment as cofinanced formats seem to compensate for a lack of employer support for NFE in some countries. Hence, referring to gross classifications of countries such as the VoC-approach for explaining cross-country differences in participation patterns for diverse NFE-formats should be regarded as a first orientating step, leading to more detailed and specified research questions. Even tough, previous analyses provide no consistent results of macro level indicators influencing incidence and inequality in access to AET, multilevel analyses controlling for e.g. (un-)employment protection or innovation indices could provide further insights into relations of company, individual and state investment in adults' further education. Furthermore, controlling for durations and aims of participation for the diverse NFE-formats could lead to a deeper understanding of diverse investment logics of different stakeholders in different countries.

Overall, promotion and support for NFE seems heterogeneous in different countries which is reflected only roughly in this paper by identifying diverse parameters influencing participation in the distinguished NFE formats by investment. Further exploration and differentiation is needed especially regarding the co-financed NFE formats. For investigating relations of investment in NFE by different stakeholders in different countries that lead to a more thorough interpretation of the interplay of supply and demand patterns, detailed information of country specific funding instruments and adult education provision should be 
referred to. Such systematic review still providing comparable information across countries is quite a difficult task (FIBS and DIE 2013). In-depth comparisons including extensive information on country specific indicators of adult education provision, funding instruments and labour market structures seems a promising strategy for further investigations. Results presented could be referred to for identifying countries showing similar resp. diverse patterns of participation in diverse formats of NFE. 


\section{References}

Allmendinger, J. (1989). Educational Systems and Labor Market Outcomes. European Sociological Review, 5(3), 231-250.

Bassanini, A., Booth, A., Brunello, G., Paola, M.D., \& Leuven, E. (2005). Workplace Training in Europe: IZA Discussion Paper No. 1640.

Bauer, G. (2010). Graphische Darstellung regressionsanalytischer Ergebnisse. In C. Wolf, \& H. Best (Eds.), Handbuch der sozialwissenschaftlichen Datenanalyse (pp. 905-927). Wiesbaden: VS, Verl. für Sozialwiss.

Behringer, F., Kuwan, H., \& Schönfeld, G. (2013). Lernen Erwachsener in Europa. In F. Bilger, D. Gnahs, J. Hartmann, \& H. Kuper (Eds.), Forschung. Weiterbildungsverhalten in Deutschland. Resultate des Adult Education Survey 2012 (pp. 332-342). Bielefeld: Bertelsmann.

Behringer, F., \& Schönfeld, G. (2012). Betriebliche Weiterbildung in Deutschland im europäischen Vergleich: Vergleichende Analysen auf der Grundlage der CVTS3-Daten. Abschlussbericht. Retrieved from Bibb website: https://www2.bibb.de/bibbtools/tools/fodb/data/documents/pdf/eb_23302.pdf.

Behringer, F., \& Schönfeld, G. (2014). C Schwerpunktthema: Lernen Erwachsener in Deutschland im europäischen Vergleich. In Bundesinstitut für Berufsbildung (BIBB) (Ed.), Datenreport zum Berufsbildungsbericht 2014. Informationen und Analysen zur Entwicklung der beruflichen Bildung (pp. 381-413). Bonn: Bertelsmann.

Best, H., \& Wolf, C. (2010). Logistische Regression. In C. Wolf, \& H. Best (Eds.), Handbuch der sozialwissenschaftlichen Datenanalyse (pp. 827-854). Wiesbaden: VS, Verl. für Sozialwiss.

Blossfeld, H.-P. (2003). Globalization, social inequality and the role of countryspecific institutions. In P. Conceição, M.V. Heitor, \& B.-Å. Lundvall (Eds.), Innovation, Competence Building and Social Cohesion in Europe. Towards a Learning Society (pp. 303-324). Northhampton: Edward Elgar.

Boateng, S.K. (2009). Significant country differences in adult learning (Statistic in Focus No. 44). Retrieved from Eurostat website: http://ec.europa.eu/eurostat/documents/3433488/5281333/KS-SF-09-044EN.PDF/82cd034b-a65f-47ca-8f62-6285ad593c20.

Boeren, E., Nicaise, I., \& Baert, H. (2010). Theoretical models of participation in adult education: the need for an integrated model. International Journal of Lifelong Education, 29(1), 45-61. doi:10.1080/02601370903471270.

Booth, A.L., Francesconi, M., \& Zoega, G. (2003). Unions, Work Related Training, and Wages: Evidence for British Men. Industrial and Labor Relations Review, 57(1), 68-91.

Bosch, G. (2010). In Qualifizierung investieren: Ein Weiterbildungsfonds für Deutschland; Expertise im Auftrag des Gesprächskreises Arbeit und Qualifizierung der Friedrich-Ebert-Stiftung. Wiso-Diskurs - Expertisen und Dokumentationen zur Wirtschafts- und Sozialpolitik. Bonn: Friedrich-EbertStiftung.

Brunello, G. (2001). On the Complementarity between Education and Training in Europe: IZA Discussion Paper No. 309. Retrieved from IZA Bonn: http://papers.ssrn.com/abstract=273040. Accessed 12 August 2015. 
Brunello, G., Garibaldi, P., \& Wasmer, E. (2007). Stylized Facts about Workplace Training. In G. Brunello, P. Garibaldi, \& E. Wasmer (Eds.), Education and Training in Europe (pp. 118-140). Oxford: Oxford University Press.

Brunello, G., Garibaldi, P., Wasmer, E. (Eds.). (2007). Education and Training in Europe. Oxford: Oxford University Press.

Brzinsky-Fay, C. (2007). Lost in Transition? Labour Market Entry Sequences of School Leavers in Europe. European Sociological Review, 23(4), 409-422. doi:10.1093/esr/jcm011.

Cedefop (2008). Sectoral training funds in Europe. Luxembourg: Cedefop.

Cedefop (2012a). Latvia VET in Europe - Country report. Retrieved from http://www.cedefop.europa.eu/en/publications-and-resources/countryreports/latvia-vet-europe-country-report-2012. Accessed 01 November 2015.

Cedefop (2012b). Lithuania VET in Europe - Country report. Retrieved from http://www.cedefop.europa.eu/en/publications-and-resources/countryreports/lithuania-vet-europe-country-report-2012. Accessed 01 November 2015.

Desjardins, R., Rubenson, K., \& Milana, M. (2006). Unequal chances to participate in adult learning: International perspectives.Paris: UNESCO.

Desjardins, R., \& Rubenson, K. (2011). OECD Education Working Papers: An Analysis of Skill Mismatch Using Direct Measures of Skills (Vol. 63). Paris: OECD.

Desjardins, R., \& Rubenson, K. (2013). Participation Patterns in Adult Education: the role of institutions and public policy frameworks in resolving coordination problems. European Journal of Education, 48(2), 262-280. doi:10.1111/ejed.12029.

Dieckhoff, M., Jungblut, J.-M., \& O'Connell, P.J. (2007). Job-Related Training in Europe: Do Institutions Matter? In D. Gallie (Ed.), Employment Regimes and the Quality of Work (pp. 77-104). Oxford: Oxford University Press.

Esping-Andersen, G. (1990). The three worlds of welfare capitalism. Princeton, N.J.: Princeton University Press.

Estevez-Abe, M., Iversen, T., \& Soskice, D. (2001). Social Protection and the Formation of Skills: A Reinterpretation of the Welfare State. In P.A. Hall, \& D. Soskice (Eds.), Varieties of Capitalism (pp. 145-183). Oxford: Oxford University Press.

European Commission (2010). Commission Regulation (EU) No 823/2010 of 17 September 2010 implementing Regulation (EC) No 452/2008 of the European Parliament and of the Council concerning the production and development of statistics on education and lifelong learning, as regards statistics on the participation of adults in lifelong learning. Official Journal of the European Union: http://eur-lex.europa.eu/legal-content/EN/TXT/?uri=celex: 32010R0823. Accessed 01 November 2015.

European Commission \& Eurostat. (2006). Classification of learning activities Manual. Luxembourg: EC and Eurostat.

European Commission \& Eurostat. (2012). Draft AES manual - Part A. Annexes 1 to 14 - FIELD WORK. Version 8.

European Commission \& Eurostat. (2013). Draft AES manual Version 9. 
European Commission \& Eurostat. (2014). Adult Education Survey 2011. EU Quality Report. (Version October 2014). Lusxemburg. Retrieved from https://circabc.europa.eu/sd/a/6b33bc1c-3906-4311-ad3f-

6c52dd1bfd53/2011\%20AES\%20EU\%20quality\%20report\%20_\%20final\%2 0October\%202014.pdf. Accessed 11 November 2014.

European Parliament and the Council of the European Union (2008). Regulation (EC) No 452/2008 of the European Parliament and of the council of 23 April 2008 concerning the production and development of statistics on education and lifelong learning. Official Journal of the European Union.

Forschungsinstitut für Bildungs- und Sozialökonomie (FIBS), \& Deutsches Institut für Erwachsenenbildung (DIE). (2013). Annex to the Final Report. Developing the Adult Sector.: Lot 2: Financing the Adult Learning Sector. Contract AEC 2012-0073. Retrieved from http://ec.europa.eu/education/library/study/2013/adult-financing_en.pdf.

Fourage, D., Schils, T., \& Grip, A. (2010). Why Do Low-Educated Workers Invest Less in Further Training? IZA Discussion Paper No. 5180. Retrieved from http://ftp.iza.org/dp5180.pdf.

Gangl, M. (2003). Bildung und Übergangsrisiken beim Einstieg in den Beruf. Zeitschrift für Erziehungswissenschaft, 6(1), 72-89. doi:10.1007/s11618-0030005-6.

GHK, \& Research voor Beleid (2011a). Country Report on the Action Plan on Adult Learning: Lithuania.

GHK, \& Research voor Beleid (2011b). Country Report on the Action Plan on Adult Learning: Latvia.

Görlitz, K., \& Tamm, M. (2011). Revisiting the Complementarity between Education and Training: The Role of Personality, Working Tasks and Firm Effects. Ruhr economic papers: Vol. 307. Essen: RWI RheinischWestfälisches Institut für Wirtschaftsforschung.

Green, A. (2006). Models of Lifelong Learning and the 'knowledge society'. Compare: A Journal of Comparative and International Education, 36(3), 307-325. doi:10.1080/03057920600872449.

Hall, P.A., \& Soskice, D. (Eds.). (2001). Varieties of Capitalism: Oxford: Oxford University Press.

Hughes, G., O’Connell, Philip J., \& Williams, J. (2004). Company training and low-skill consumer-service jobs in Ireland. International Journal of Manpower, 25(1), 17-35.

Kaufmann, K., \& Widany, S. (2013): Berufliche Weiterbildung - Gelegenheitsund Teilnahmestrukturen. Zeitschrift für Erziehungswissenschaft (ZfE), 16(1), 29-54.

Markowitsch, J., Käpplinger, B., \& Hefler, G. (2013). Firm-provided Training in Europe and the Limits of National Skills Strategies. European Journal of Education, 48(2), 281-291. doi:10.1111/ejed.12030.

Mytzek-Zühlke, R. (2007). Einflussfaktoren betrieblichen Weiterbildungshandelns im internationalen Vergleich. AStA Wirtschafts- und Sozialstatistisches Archiv, 1(3-4), 217-232. doi:10.1007/s11943-007-0024-5.

Nölke, A., \& Vliegenthart, A. (2009). Enlarging the Varieties of Capitalism: The Emergence of Dependent Market Economies in East Central Europe. World Politics, 61(4), 670. doi:10.1017/S0043887109990098. 
Reichart, E., \& Kaufmann, K. (2015): Investment patterns in vocational Adult Education and Training in international comparison - Differences of results by distinguishing and combining FED and NFE. Presentation. 4th European User Conference for EU-Microdata, GESIS in cooperation with Eurostat, Mannheim.

Riphahn, R.T., \& Trübswetter, P. (2007). Population Aging and Trends in the Provision of Continued Education (Research Notes No. 11). Retrieved from Council for Social and Economic Data (RatSWD) website: http://www.ratswd.de/download/RatSWD_RN_2007/RatSWD_RN_11.pdf.

Roosmaa, E.-L., \& Saar, E. (2010). Participating in non-formal learning: patterns of inequality in EU-15 and the new EU-8 member countries. Journal of Education and Work, 23(3), 179-206. doi:10.1080/13639080.2010.486396.

Roosmaa, E.-L., \& Saar, E. (2012). Participation in non-formal learning in EU-15 and EU-8 countries: demand and supply side factors. International Journal of Lifelong Education, 31(4), 477-501. doi:10.1080/02601370.2012.689376.

Rubenson, K., \& Desjardins, R. (2009). The Impact of Welfare State Regimes on Barriers to Participation in Adult Education: A Bounded Agency Model. Adult Education Quarterly, 59(3), 187-207. doi:10.1177/0741713609331548.

Rubenson, K. (2006). The Nordic model of Lifelong Learning. A Journal of Comparative and International Education, 36(3), 327-341. doi: 10.1080/03057920600872472.

Saar, E., \& Ure, O.B. (2013). Lifelong learning systems: overview and extension of different typologies. In E. Saar, O.B. Ure, \& J. Holford (Eds.), Lifelong learning in Europe. National patterns and challenges (pp. 46-81). Cheltenham, UK: Edward Elgar.

Saar, E., Ure, O.B., \& Holford, J. (Eds.). (2013). Lifelong learning in Europe: National patterns and challenges. Cheltenham, UK: Edward Elgar.

Schiener, J. (2006). Bildungserträge in der Erwerbsgesellschaft. Wiesbaden: VS Verl. für Sozialw.

Schönfeld, G., \& Behringer, F. (2013). Betriebliche Weiterbildung in Deutschland im europäischen Vergleich: Ergebnisse der dritten europäischen Erhebung zur betrieblichen Weiterbildung (CVTS3). Wissenschaftliche Diskussionspapiere des Bundesinstituts für Berufsbildung: Vol. 141.

Schönfeld, G., \& Behringer, F. (2015). Betriebliche Weiterbildung aus Sicht der Erwerbstätigen im europäischen Vergleich. In Bundesinstitut für Berufsbildung (BIBB) (Ed.), Datenreport zum Berufsbildungsbericht 2015. Informationen und Analysen zur Entwicklung der beruflichen Bildung (pp. 306-314). Bonn: BiBB.

Seifried, J., \& Berger, S. (2011). Determinanten der Weiterbildungsbeteiligung. Zeitschrift für Berufs- und Wirtschaftspädagogik, 107(1), 138-152.

Shavit, Y., Müller, W., \& Tame, C. (1998). From school to work: A comparative study of educational qualifications and occupational destinations. Oxford: Oxford University Press.

Tuor Sartore, S.N., \& Backes-Gellner, U. (2014). Employer-Supported Training as a Non-Wage Compensation Component. Die Betriebswirtschaft (DWB), 74(2), 87-105. 